Article

\title{
The Beginning of Western Greek Amphorae Production in Western Sicily: Archaeometric and Archaeological Studies on 6th-5th Centuries BCE Amphorae Manufactured in Himera
}

\author{
Giuseppe Montana ${ }^{1}$, Luciana Randazzo ${ }^{2, *(D)}$ and Babette Bechtold ${ }^{3, *}$ \\ 1 Dipartimento di Scienze della Terra e del Mare (DiSTeM), University of Palermo, Via Archirafi, \\ 22-90123 Palermo, Italy; giuseppe.montana@unipa.it \\ 2 Dipartimento di Biologia, Ecologia e Scienze della Terra (DiBEST), University of Calabria, Via P. Bucci, \\ Cubo 12B, 87036 Arcavacata di Rende, Italy \\ 3 Institut für Klassische Archäologie, Universität Wien, Franz Klein-Gasse 1, 1190 Wien, Austria \\ * Correspondence: luciana.randazzo@unical.it (L.R.); babette.bechtold@univie.ac.at (B.B.)
}

Received: 21 July 2020; Accepted: 26 August 2020; Published: 27 August 2020

\begin{abstract}
About 560 western Greek amphorae (6th-5th centuries BCE) re-used in enchytrismos burials were unearthed in the necropolis of the Dorian-Chalcidian colony of Himera in northwestern Sicily. Among the most striking issues is the determination of their geographical provenance. For this purpose, ceramic samples chipped from freshly broken surfaces of all the amphorae were first subdivided into macrofabrics by the use of a hand lens. Thereon, the samples were studied in accordance with standardized methods by the use of reflected light microscopy. Due to the special focus of our project on the characterization of Sicilian productions, a selection of amphorae which showed visible, macroscopic affinities with the majority of the macrofabrics previously attributed to the region of Himera was submitted for thin-section petrography at the polarizing microscope and chemical analyses (ICP-MS and ICP/OES). This new data set was compared with reference samples investigated by previous research, referring to ceramic raw clays of the colony's territory and local tablewares of the Iato K480-type. Our study confirms the local manufacture of the entire selection of transport vessels. The identification of a production of western Greek wine (?) amphorae in Himera dating mainly from the third quarter of the 6th to the first quarter of the 5th century BCE breaks new grounds in view of a better interpretation of the colony's economic development during the later archaic period. Furthermore, it underlines Himera's prominent position within the wider frame of regional economic interaction.
\end{abstract}

Keywords: Sicily; Himera; western Greek amphorae; local production; petrography; chemical analyses

\section{Introduction}

\subsection{Archaeological Background and Aims}

Himera, the westernmost Greek city along Sicily's Tyrrhenian coast, was founded shortly after the mid-7th century BCE by a joint group of Dorian-Chalcidian colonists. Both its geographic location at the northwestern edge of the Himera plain, on the mouth of the river Imera Settentrionale, and the ample agricultural and pastoral hinterland at its disposal, favored a rapid urbanistic and economic development, especially during the 6th century BCE (Figure 1A,B). The most prominent historical episode related to Himera is the famous battle of $480 \mathrm{BCE}$ fought in front of the city's western fortifications, when a Greek alliance defeated the Carthaginians. However, in 409 BCE and shortly 
after the sack of Selinunte on Sicily's southwestern coast, the Carthaginian army under the leadership of Hannibal advanced rapidly to the north and destroyed Himera, which was never systematically re-occupied thereafter (in detail: [1]).
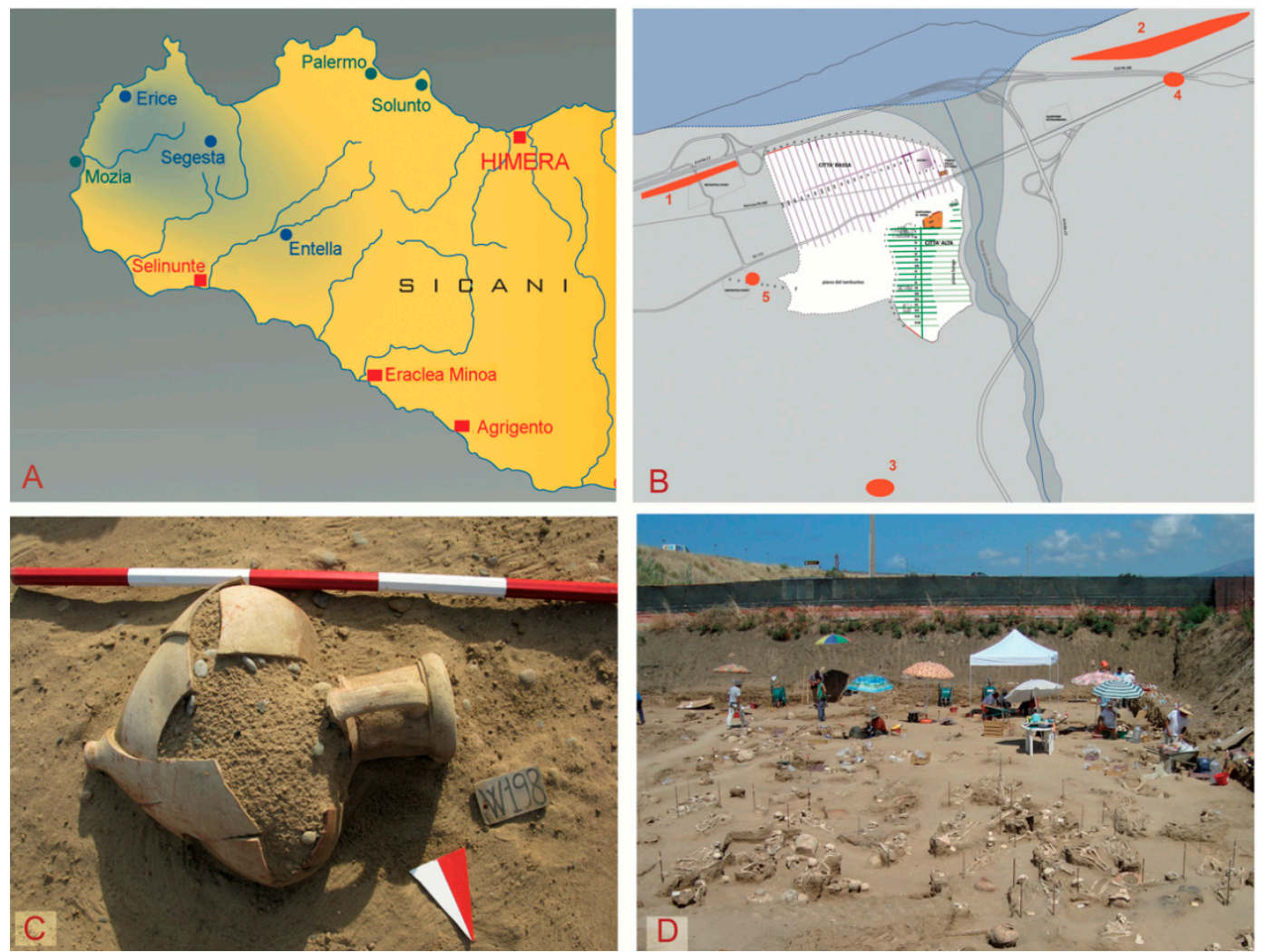

Figure 1. (A) Geographical localization of Himera; (B) planimetry of Himera; (C) western Greek amphora produced in Himera; (D) excavations in the western necropolis of Himera.

This paper focuses on a selection of 36 western Greek amphorae presumably produced in Himera during the second half of the 6th-5th centuries BCE (Figure 1C). The term "western Greek" denotes transport vessels manufactured by export-orientated Greek colonies of Magna Graecia and Sicily during the archaic-classical period (at the latest: [2-4]; for Sicily see specifically [5]). The amphorae discussed in the present contribution have been re-used in the necropolis of Himera in enchytrismoi, that is, in burials of infants in large containers, and unearthed in excavations undertaken by the Soprintendenza BB.CC.AA. di Palermo (Figure 1D) during the last 25 years ([6] with earlier references). On the basis of both context dating and morphological comparisons, at present, the hypothetically local series represents the earliest amphora production of colonial Greek Sicily. The present joint study offers an archaeometric and archaeological characterization of western Greek amphorae manufactured in Himera (for a similar study on southern Campanian amphorae found in Himera, see [7]). It constitutes a benchmark for further research on the role of Sicily's westernmost Greek colony within the wider frame of the regional and supraregional commercial interaction between Greek, Punic and native communities in this border-region.

Presumably, pottery production in Himera had started already during the last quarter of the 7th century BCE, guided by the necessity to provide the colony with its ceramic everyday crockery [8]. Unfortunately, up to date archaeological excavations carried out in many areas of the polis of Himera have not brought to light ceramic kilns, structures or materials (e. g., tanks, raw clays, temper), which can be directly connected to the fabrication of daily-use pottery or amphorae $[1,6,8]$. However, production indicators such as spacers and valves have been yielded in several excavation areas opened across the urban area [9]. Potential structural evidence for a small ceramist's workshop was found 
in block XIII, in the lower city, but no assessment can be made on the effective activity of this facility. About $40 \mathrm{~m}$ south of this location, a bell-shaped kiln cut into the lower part of the bedrock was identified, which had been mostly destroyed during the 1970s by an excavator's shovel [8].

By consequence, in the last thirty years, local ceramic fabric has been recognized by minero-petrographic and chemical appraisals between clayey ceramic raw materials outcropping near the site (and after experimental firing tests) and a reasonable number of ceramic samples (mainly tablewares) attributed to the production of Himera in consideration of significant, archaeological criteria. A first, joint archaeological and archaeometric research has allowed for the attribution of the class of kylikes Iato K480 to late archaic workshops of Himera [10-12]. Contemporaneously, the clay raw materials available in the surrounding territory have been subjected to experimental firing and compared (petrographically and chemically) with the corresponding ceramic finds [11,13-17].

Archaeometric studies of ceramic artifacts generally focus on cross-correlations and grouping-procedures aimed at more complex interpretations, e.g., archaeological, historical or technological issues. A "ceramic group" (both on a minero-petrographic and/or chemical basis) is composed of a set of ceramic samples characterized by common textural and compositional aspects. The typological and/or chronological analogies between the samples referred to the same paste group and their assignment to a specific archaeological context reinforces the representativeness of the group itself, which can therefore be considered a "reference group" for a given ceramic production [18]. Furthermore, study by thin-section microscopy of the ceramic paste offers a solid basis for the correct identification of fabric characteristics, which can be appreciated macroscopically, that is to say, by the use of a hand lens or a stereo-microscope. As a positive inference, archaeologists are able to perceptibly reduce attribution errors of so-called defined ceramic fabrics among large quantities of finds.

Within the scope of archaeological provenance studies on central-Mediterranean pottery, in 2011, several macrofabrics of fine wares, coarse wares, pithoi and tiles, all yielded in the western necropolis of Himera and attributed to the "region of Himera" by the excavator Stefano Vassallo, have been included in the database of FACEM (=Fabrics of the Central Mediterranean) [19]. However, notwithstanding the identification of a vigorous tableware production from the early archaic period onwards, the issue of a possible, local amphorae series remained unresolved.

The in-depth study (for the project, see acknowledgment) of about 560 western Greek amphorae of different geographic origins and re-used in enchytrismos burials of Himera's cemeteries provided a unique opportunity to re-evaluate the whole question. Among the principal goals of this still on-going research is the provenance determination of archaeologically and archaeometrically well defined groups. For this purpose, ceramic samples chipped from freshly broken surfaces of nearly 560 amphorae were subdivided into macrofabrics by the use of a hand lens. Thereon, all of the samples were studied in accordance with standardized methods implemented for FACEM [20] and compared with reference samples of fabrics already defined by archaeometric analyses. Representative selections of every macrofabric were submitted for petrographic analyses. Due to the special focus of our project on the characterization of Sicilian productions, in this paper, a selection of presumed local macrofabrics has been submitted for detailed petrographic and chemical analyses.

\subsection{Archaeological Data on the Studied Amphorae Materials}

The FACEM recording procedure outlined above allowed for the identification of a selection of 36 amphorae which showed visible, macroscopic affinities with the majority of the macrofabrics previously attributed to the region of Himera [19]. The study under the stereo-microscope of these 36 samples of presumably local amphorae led to the distinction of two subgroups, both distinguished by a reddish-brown or brown matrix (for the macroscopic description, see in detail: [21]), a coarser one with the clearly visible, possibly intentional addition of a coarse sand temper (HIM-A-1, Figure 2A) and a fine/very fine one, presumably without or with finer additives (HIM-A-2, Figure 2B). 


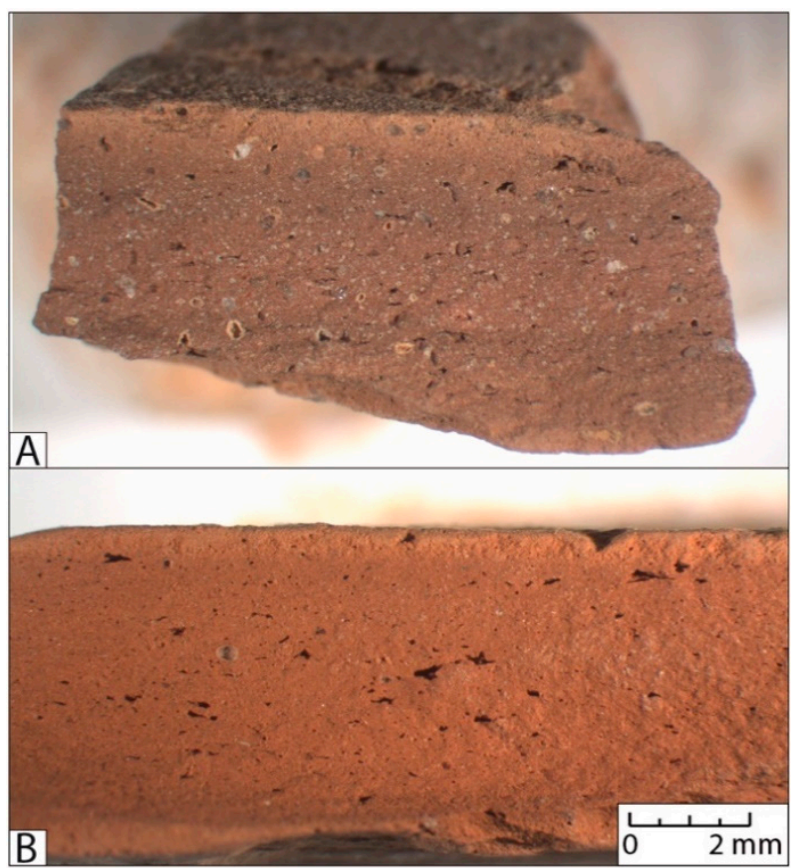

Figure 2. Archaeological fabrics of western Greek amphorae produced in Himera. (A) Him-A-1: M 179/160; (B) HIM-A-2: M 179/234.

In the following, five samples of the first and 11 samples of the second selection (Table 1) were submitted for mineral-petrographic analysis (Section 3.1). Furthermore, 11 samples underwent chemical analysis (Section 3.2).

Table 1. Synopsis of data related to western Greek amphorae produced in Himera and provided with petrographic analysis. Typological identification referred to [22].

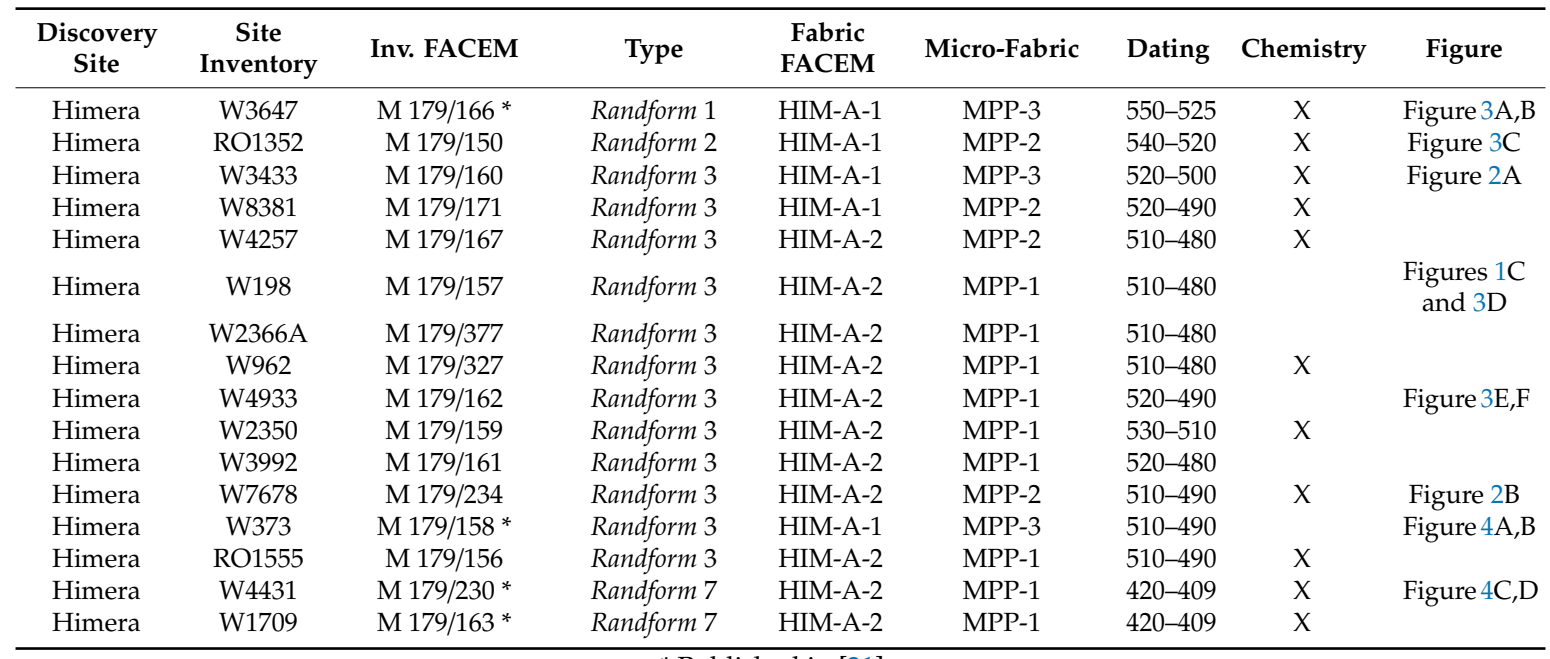

* Published in [21]. 

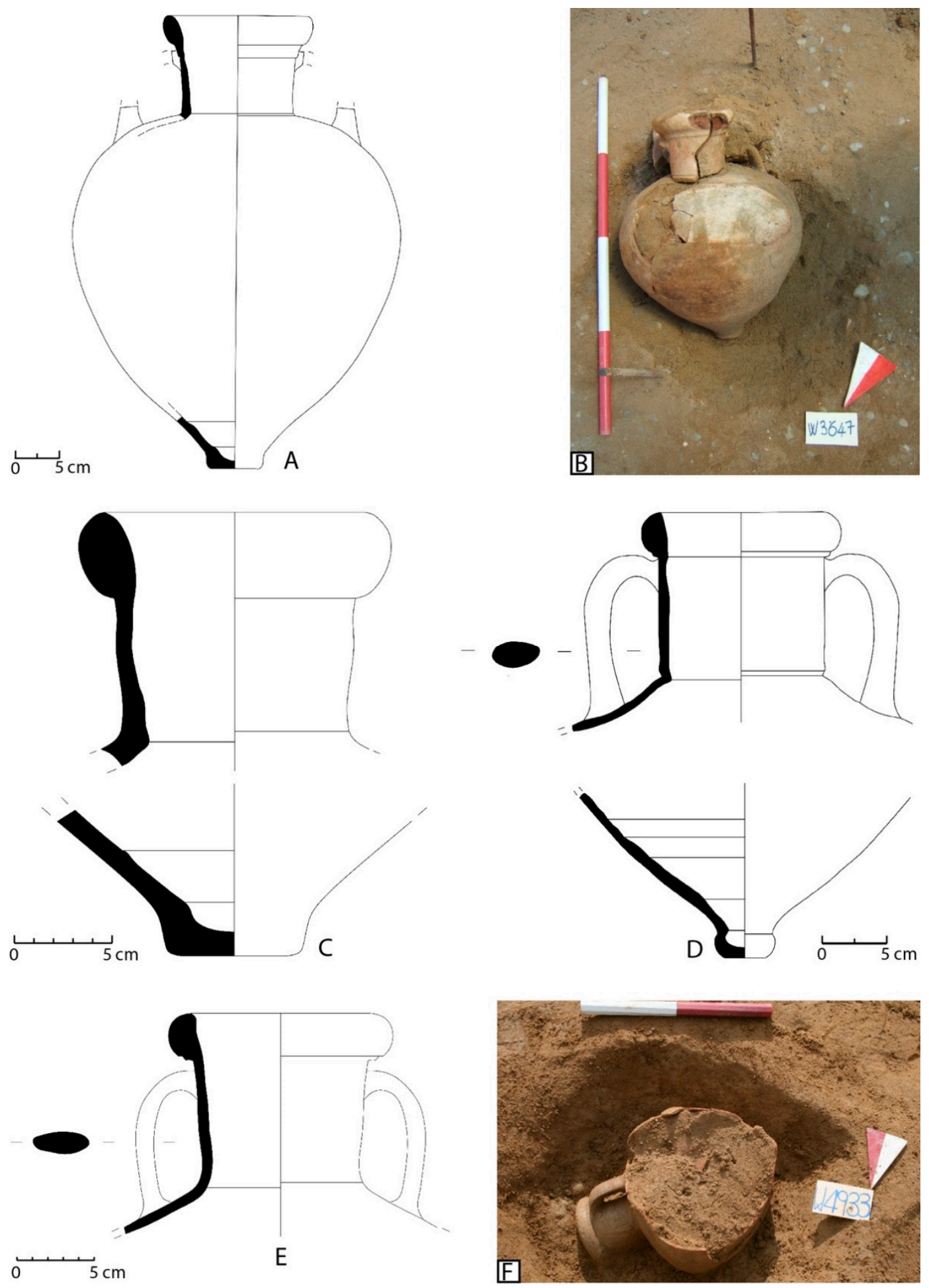

Figure 3. Amphora production of Himera, Randform 1 (A,B) W3647/M 179/166; Randform 2 (C) RO1352/M 179/150; Randform 3, variant A (D) W198/M 179/157 (E,F) W4933/M 179/162. 


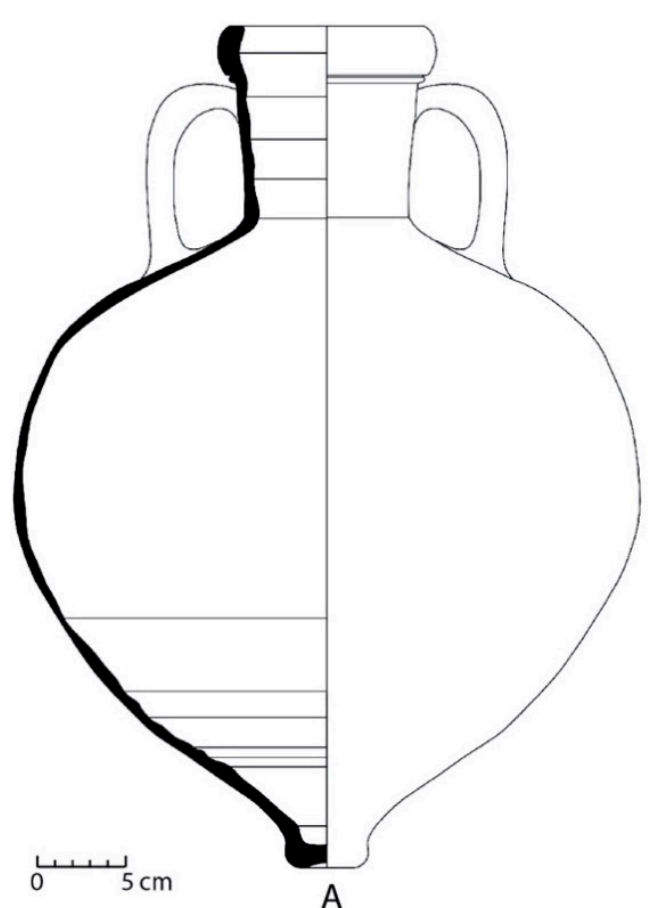

A

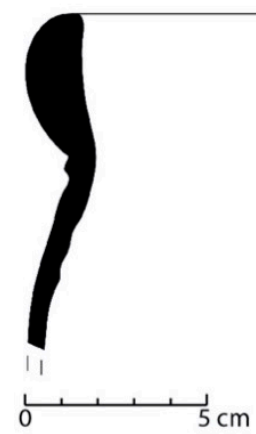

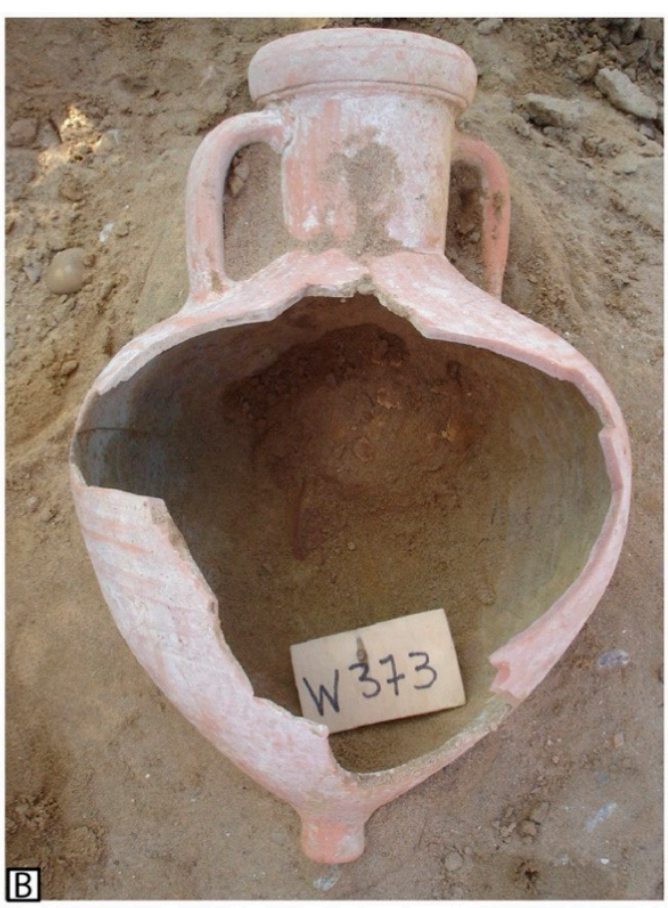

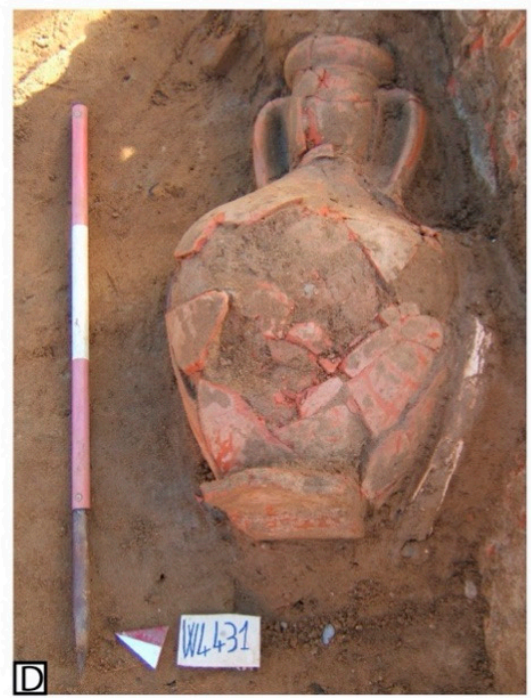

Figure 4. Amphora production of Himera, Randform 3, variant B. (A,B) W373/M 179/158; Randform 7 (C,D) W4431/M 179/230.

The first archaeological and historical observations on the production of western Greek amphorae in Himera were proposed in a previous paper [21], which will be briefly summarized in the following: the earliest local amphora can be classified as form $1 \alpha$ of $\mathrm{Ch}$. Sourisseau's typology [4]. It has been dated, by context and on the basis of morphological comparisons, to the third quarter of the 6th century BCE (Figure 3A,B). Among the local group from the necropolis, this shape is probably attested by only two items. It shows an ovoid-shaped rim and a cylindrical neck characterized by a ridge at its higher portion like in Randform 1 [22], a subovoid body and a large, flat basis.

One amphora with an ovoid-shaped rim of Randform 2 with a short, cylindrical neck and a large, flat resting surface (Figure 3C) might be placed, for morphological reasons, in between the earliest and the late archaic group (see below), with a chronological range somewhere within the second half of the 6th century BCE. Remarkably, all archaic vessels with Randformen 1-2 show the coarser macrofabric HIM-A-1. 
Over the course of the last two decades of the 6th and the earlier 5th century BCE, local potters started the production of subglobular and heart-shaped form 2 amphorae [4] provided by Randform 3 [22] in two variants: with massive semi-ovoid rims (Figure 3D-F) or with elongated semi-ovoid rims (Figure 4A,B), both distinguished by strongly profiled, inferior edges. This group is best attested by about 30 items, which are well dated to the late archaic period by the association, within three of the graves, of two black figure lekythoi and a local kotyliskos. The majority of the amphorae with Randform 3 is made of macrofabric HIM-A-2, but more than a third present still the coarser macrofabric HIM-A-1.

Presently, we do not have any secure evidence for local amphorae dating to the second or third quarter of the 5th century BCE. Amphorae production in Himera was documented again during the last decade of the colony's existence, when we found two vessels (Figure 4C-D) with elongated, ovoid bodies, more or less convex necks and rims of Randform 7 [22]. Both items are characterized by a very fine variant of macrofabric HIM-A-2.

\subsection{Ceramic Raw Clays in Himera's Territory}

Himera developed in the San Nicola plateau, about $1.5 \mathrm{~km}$ from the coastline-a terrace of alluvial origin between the Imera Settentrionale river to the east and the Fiume Torto river to the west (Figure 5).

The geological formations that outcrop out in the area are represented by the units deriving from the deformation of the Sicilide domain [23-25]. From the bottom to the top, they are: (1) Argille Varicolori Inferiori (Upper Cretaceous-Paleocene), mainly consisting of varicolored argillites with a scaly structure (in shades of greenish gray, wine red, brick red, yellow ocher or whitish gray when altered) and, subordinately, marls, micaceous sandstones and calcilutites; (2) Polizzi Formation (Middle Eocene-Oligocene), composed by well-layered calcilutites and whitish marly limestones alternating with grayish marly levels rich in planktonic foraminifers and calcareous nannofossils; (3) Terravecchia Formation (Upper Tortonian-Lower Messinian), synorogenic clastic deposits including terrigenous deposits, very different in terms of grain-size distribution, represented by (from bottom to top): conglomerates with sand-silty matrix with carbonate, arenaceous and acid crystalline elements; sands and quartz sandstones, gray-yellowish in color, with small-sheet mica crystals; bluish-gray silty clays with foraminifera and calcareous nannofossils passing downwards with sandy and bluish pelite clays with important local arenitic intercalations; (4) Baucina Formation (Upper Tortonian-Lower Messinian), biocalcarenites and calcirudites with fragments of Porites sp. and marly calcareous arenites (clastic-carbonate facies); (5) Gessoso-Solfifera Group (Messinian), greenish gray gypsum arenite, laminated gypsum siltite, massive and/or poorly stratified selenitic gypsum; (6) Trubi Formation (Lower Pliocene-Middle Pliocene), a rhythmic alternation of yellowish-white marl and limestone rich in calcareous plankton (layers mostly $20-30 \mathrm{~cm}$ thick), almost devoid of terrigenous fraction; (7) alluvial deposits (Upper Pleistocene-Holocene).

On the basis of the lithostratigraphic succession described above, it is evident that within a radius of about ten kilometers from the site of Himera, there are only two formations which, potentially, can supply raw clay materials that can be used for ceramic production: the Argille Varicolori Inferiori (AVF) and the clayey member of the Terravecchia Formation.

The AVF argillites outcropping in the area are typically poor in $\mathrm{CaO}(<2 \%$ by weight $)$ and show a modest "plastic" behavior with average linear shrinkage (LS) values up to $16 \%$ at $900{ }^{\circ} \mathrm{C}$, thus being moderately appropriate as a ceramic raw material for use on the pottery wheel. In western Sicily, the use of these clayey materials is conducted only occasionally for the production of bricks and tiles $[14,15]$. In contrast, the clayey member of the Terravecchia Formation can be considered certainly the most used ceramic raw material western Sicily as a whole, from the archaic times right up to the present day. It does not require any special pretreatment. In its natural state, the clays from the Terravecchia Formation have optimal minero-petrographic, chemical and technological characteristics. They are characterized by good plasticity for ceramic manufacture using a pottery wheel, a satisfactory linear shrinkage after firing (LS $=12 \%$ at $900{ }^{\circ} \mathrm{C}$ measured in clay sampled at Contrada Bovitello (site 2 
in Figure 5), at short distance from the excavations of Himera), as well as a fairly uniform color after firing in an oxidizing atmosphere $[16,17]$.

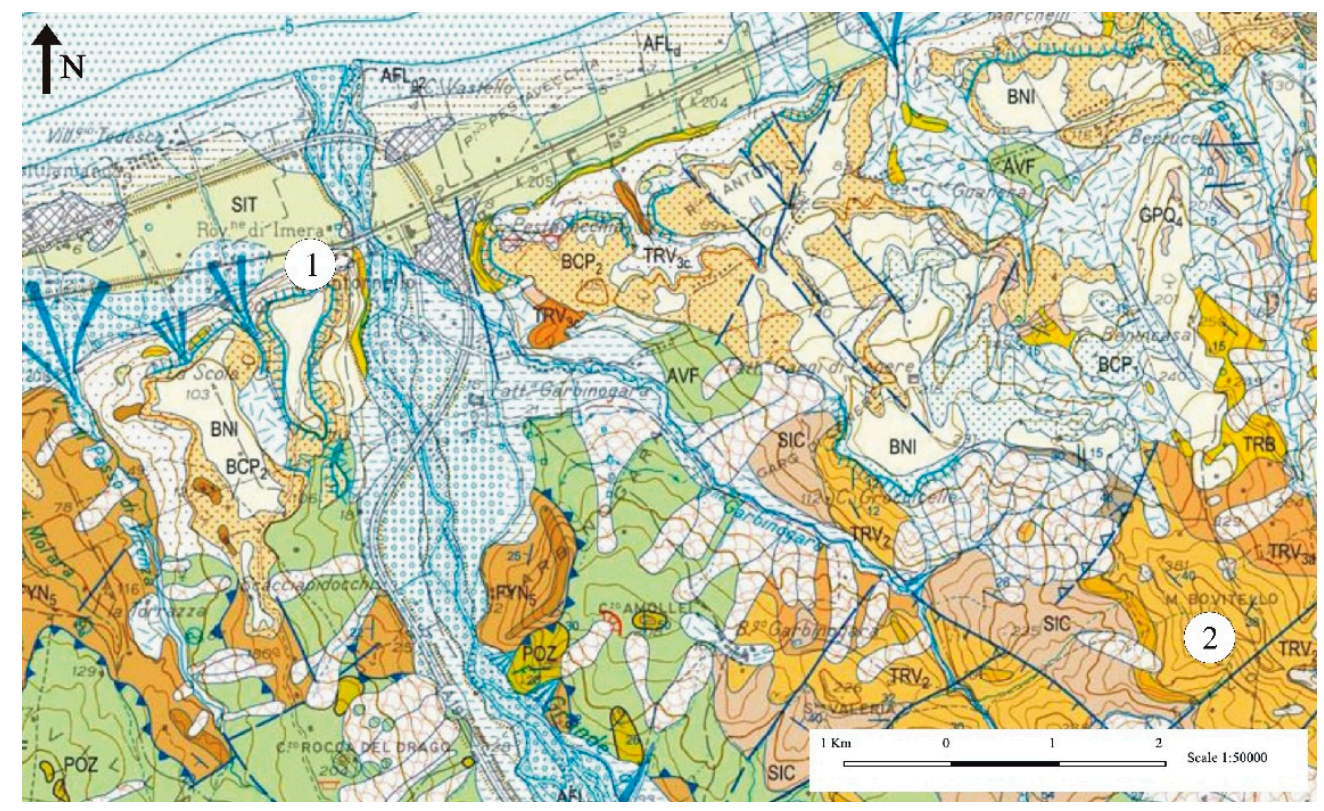

Figure 5. Geological map of the area of Himera (simplified after [25]). Sites 1 and 2 (circled) correspond to the Himera archaeological site and Mt Bovitello, respectively. Codes of Formations that outcrop in the territory of Himera are provided here: AFL = Synthem of Capo Plaia (Upper Pleistocene-Holocene); SIT $=$ Synthem of Barcarello (Pleistocene); BNI = Synthem of Benincasa (Upper-Middle Pleistocene); BCP = Synthem of Buonfornello-Campofelice (Middle Pleistocene); TRB = Trubi (Zanclean), GPQ4 $=$ Pasquasia Formation (Lower Messinian); TRV = Terravecchia Formation, namely TRV3 ${ }_{(\mathrm{a}-\mathrm{b}-\mathrm{c})}$ is the Pelitic member, while TRV2 is the sandstone one (Upper Tortonian-Lower Messinian); SIC = Castellana Sicula Formation (Serravallian-Lower Tortonian); POZ = Polizzi Formation (Upper-Middle Eocene); AVF = Argille Varicolori Inferiori (Upper Cretaceous-Paleocene); FYN5 = Numidian Flysch (Upper Oligocene-Lower Miocene). The full legend is accurately reported in [25].

\section{Materials and Methods}

Thin-section petrographic observations were carried out by means of a Leica DC 200 polarizing microscope (Leica Microsystems, Wetzlar, Germany) equipped with a digital camera. The relative abundance of nonplastic inclusions (expressed as area \%) was determined by conventional point-counting procedures [26]. Bulk chemical data were determined at Activation Laboratories Ltd. (Ancaster, ON, Canada), using fusion inductively coupled plasma optical emission spectrometry (ICP-OES) for determining major elements and inductively coupled plasma mass spectrometry (ICP-MS) for trace elements.

Samples were first air-dried, ground and homogenized in a planetary agate ball-mill (Retsch PM100, Retsch GmbH, Haan, DE, Germany). Samples were prepared and analyzed in a batch system. Each batch contains a method reagent blank, certified reference materials and some replicates. Samples were mixed with a flux of lithium metaborate and lithium tetraborate and fused in an induction furnace. The molten melt is immediately poured into a solution of $5 \%$ nitric acid containing an internal standard until completely dissolved.

The samples were run for major oxides and selected trace elements on a combination of simultaneous/sequential Thermo Jarrell-Ash ENVIRO II ICP (Thermo Fisher Scientific, Waltham, MA, USA) or a Varian Vista 735 ICP (Agilent Technologies, Inc., Santa Clara, CA, USA). Calibration was performed using 7 prepared USGS- and CANMET-certified reference materials. One of the 7 standards was used during the analysis for every group of ten samples. Twenty-four elements were considered 
here: $\mathrm{Na}, \mathrm{Mg}, \mathrm{Al}, \mathrm{Si}, \mathrm{P}, \mathrm{K}, \mathrm{Ca}, \mathrm{Ti}, \mathrm{Mn}$ and $\mathrm{Fe}$ (given as oxides, wt \%) and $\mathrm{Cr}, \mathrm{V}, \mathrm{Cu}, \mathrm{Zn}, \mathrm{Rb}, \mathrm{Sr}, \mathrm{Y}, \mathrm{Zr}, \mathrm{Ba}$, $\mathrm{Pb}, \mathrm{Ce}, \mathrm{Nb}$, La and $\mathrm{Ni}$ (ppm). The results were then normalized on a dry-weight basis.

Both petrographic and chemical data of the samples analyzed in this work were then compared with previous analysis performed on ceramic samples produced in Himera $[11,14,15,17]$.

\section{Results}

The observations by the polarizing microscope first enabled the confirmation that all the studied amphorae, selected for thin-section petrography, can be attributed to local ceramic production that employed the raw clays belonging to the Terravecchia Formation. Moreover, the correspondence between the macroscopically defined fabric HIM-A-1 and HIM-A-2 with those identified by thin-section petrography (described in detail below) can be considered more than acceptable (sample attribution matching up to the $90 \%$ threshold). This result confirms the good reliability of the "autoptic" observation method when it is based on the selection of a statistically significant sample (here up to 560 individuals) and corroborated by previous experimental works on local clayey materials. Of course, in this case study, the opportunity to compare the amphora's microfabric with that corresponding to locally produced tableware has been of great help in corroborating the above statement.

\subsection{Petrography}

The results of the minero-petrographic study of the 16 western Greek amphorae produced in Himera are summarized in Table 2. The macroscopically defined fabrics HIM-A-1 (relatively coarser) and HIM-A-2 (very fine) after the thin-section observation at the polarizing microscope can be further subdivided into three microfabrics (hereafter, minero-petrographic pastes MPP-1, MPP-2 and MPP-3), which have somewhat similar qualitative mineralogical composition of aplastic inclusions, but simultaneously, have quite different textural features (i.e., grain-size distribution and aplastic abundance or packing).

Minero-petrographic paste MPP-1 was by far the most frequent (10 samples out of 16) and was characterized by the clear prevalence of aplastic inclusions falling in the coarse silt class $(0.04-0.06 \mathrm{~mm})$. Fine to medium sand grains were very rare $(0.1-0.3 \mathrm{~mm})$ and packing turns out to be between $3 \%$ and $5 \%$ or even $<3 \%$. Grain sorting was serial, and the ground-mass was optically inactive with sporadic clay lumps. The aplastic inclusions were mainly composed of monocrystalline quartz, followed by visibly minor quantities of polycrystalline quartz, white mica needles (homogeneously dispersed in the ground-mass) and feldspars. Small lithic fragments (quartzarenite/quartzsiltite) were rarer (at most 1-3 grains) or even absent. The calcareous microfossils (or what remains of them after the transformation following the firing process) were sporadic, while some amount of secondary burial calcite was always present in the ground-mass, or else in the form of a thin incrustation (a few tenths of a millimeter) in the external parts of the ceramic fragment (Figure 6A,B).

The minero-petrographic paste MPP-2 was relatively less frequent ( 3 samples out of 16). It was in turn characterized by abundant coarse silt $(0.04-0.06 \mathrm{~mm})$ but also had significant quantities of fine sand $(0.125-0.25 \mathrm{~mm})$. Medium sand inclusions $(0.25-0.5 \mathrm{~mm})$ were again sporadic to rare. Packing was noticeably higher than MPP-1, ranging between $10 \%$ and $15 \%$. Grain sorting was serial, and the ground-mass was optically inactive with sporadic clay lumps. Among the aplastic inclusions, monocrystalline quartz was abundant, while polycrystalline quartz, K-feldspar and mica were common to sporadic. Plagioclase and lithic fragments (quartzarenite, acid crystalline rocks) were rare. Micritic clots formed after decomposition by heating of the primary calcareous microfossils [27] and secondary microcrystalline calcite impregnations within the groundmass were common to sporadic as well as pore casts having approximately rounded or irregular shapes (Figure $6 \mathrm{C}, \mathrm{D}$ ). 
Table 2. Schematic description of the compositional and textural features of the studied western Greek amphorae.

\begin{tabular}{|c|c|c|c|c|c|c|c|c|c|c|c|c|}
\hline \multirow[b]{2}{*}{$\begin{array}{l}\text { Sample Code } \\
\text { (Micro-Fabric) }\end{array}$} & \multicolumn{8}{|c|}{ Aplastic inclusions } & \multicolumn{3}{|c|}{ Groundmass } & \multirow[b]{2}{*}{$\begin{array}{l}\text { Secondar } \\
\text { Calcite }\end{array}$} \\
\hline & Distribution & Sorting & $\begin{array}{l}\text { Aplastic Grain Size } \\
\text { Distribution }\end{array}$ & $\begin{array}{l}\text { MGS } \\
(\mathrm{mm})\end{array}$ & $\begin{array}{l}\text { Packing } \\
\quad(\%)\end{array}$ & Monomineralic Grains & Rock Fragments & $\begin{array}{l}\text { Microfossils/ } \\
\text { Limestones/ } \\
\text { Micritic Clots }\end{array}$ & $\begin{array}{l}\text { Clay } \\
\text { Lumps }\end{array}$ & $\begin{array}{l}\text { Optical } \\
\text { Activity }\end{array}$ & Porosity & \\
\hline M 179/156 (MPP-1) & MHo & Serial & $\begin{array}{l}\text { coarse silt-very } \\
\text { fine sand (rare) }\end{array}$ & $0.5^{(*)}$ & $<3 \%$ & $\mathrm{Qtz}(++), \mathrm{Qtz}$ pol (r), $\mathrm{Ms}(+)$ & & + & + & inactive & $\begin{array}{l}\text { vugs, } \\
\text { cast }\end{array}$ & $+(* *)$ \\
\hline M 179/157 (MPP-1) & мHo & Serial & $\begin{array}{l}\text { coarse silt-very } \\
\text { fine sand (sporadic) }\end{array}$ & 0.3 & $3-5 \%$ & $\begin{array}{c}\mathrm{Qtz}(+++), \operatorname{Qtz} \text { pol }(+), \mathrm{Ms} \\
(+), \mathrm{Kfs}(\mathrm{r})\end{array}$ & - & + & + & inactive & $\begin{array}{l}\text { vugs, } \\
\text { cast }\end{array}$ & + \\
\hline M 179/159 (MPP-1) & мHo & Serial & $\begin{array}{c}\text { coarse silt-very } \\
\text { fine sand (sporadic) }\end{array}$ & $0.4^{(*)}$ & $<3 \%$ & $\begin{array}{l}\text { Qtz (+++/+++), Qtz pol (+), } \\
\text { Ms (+), Kfs (+), Pl (r) }\end{array}$ & quartzsiltites $(\mathrm{r})$ & + & + & inactive & cast & $+(* *)$ \\
\hline M 179/161 (MPP-1) & MHo & Serial & $\begin{array}{l}\text { coarse silt-fine } \\
\text { sand (rare) }\end{array}$ & 0.4 & $3-5 \%$ & $\begin{array}{l}\text { Qtz (+++/++), Qtz pol } \\
(++/+), \operatorname{Ms}(+), \mathrm{Pl}(\mathrm{r})\end{array}$ & $\begin{array}{l}\text { quartzarenites/quartzsiltites } \\
\text { (r) }\end{array}$ & $+/ \mathrm{r}$ & + & inactive & $\begin{array}{l}\text { vugs, } \\
\text { cast }\end{array}$ & - \\
\hline M 179/162 (MPP-1) & мHo & Serial & $\begin{array}{c}\text { coarse } \\
\begin{array}{c}\text { silt-medium sand } \\
\text { (rare) }\end{array} \\
\end{array}$ & 0.4 & $3-5 \%$ & $\begin{array}{c}\text { Qtz (++), Qtz pol (+), Ms } \\
(++++), \mathrm{Kfs}_{(\mathrm{r})}\end{array}$ & quartzsiltites (r) & $\mathrm{r}$ & + & inactive & $\begin{array}{l}\text { vugs, } \\
\text { cast }\end{array}$ & + \\
\hline M 179/163 (MPP-1) & MH & Serial & $\begin{array}{l}\text { coarse silt-fine } \\
\text { sand (rare) }\end{array}$ & 0.3 & $3-5 \%$ & $\begin{array}{c}\mathrm{Qtz}(++), \mathrm{Qtz} \text { pol }(+/ \mathrm{r}), \mathrm{Ms} \\
(+/ \mathrm{r}), \mathrm{Kfs}(+/ \mathrm{r})\end{array}$ & $\begin{array}{l}\text { quartzarenites/quartzsiltites } \\
(\mathrm{r})\end{array}$ & + & + & inactive & $\begin{array}{l}\text { vugs, } \\
\text { cast }\end{array}$ & - \\
\hline M 179/230 (MPP-1) & $\mathrm{Ho} / \mathrm{MHo}$ & Serial & $\begin{array}{l}\text { coarse silt-fine } \\
\text { sand (rare) }\end{array}$ & 0.3 & $3-5 \%$ & $\begin{array}{c}\mathrm{Qtz}(+++), \mathrm{Qtz} \text { pol (++/+), } \\
\mathrm{Ms}(++), \mathrm{Kfs}(+), \mathrm{Pl}(\mathrm{r})\end{array}$ & - & + & + & inactive & $\begin{array}{l}\text { vugs, } \\
\text { cast }\end{array}$ & ++ \\
\hline M 179/234 (MPP-1) & мHo & Serial & $\begin{array}{c}\text { coarse } \\
\begin{array}{c}\text { silt-medium sand } \\
\text { (rare) }\end{array}\end{array}$ & 0.6 & $3-5 \%$ & $\begin{array}{c}\text { Qtz }(+++), \operatorname{Qtz} \text { pol }(++), \mathrm{Ms} \\
(+), \mathrm{Kfs}(+)\end{array}$ & $\begin{array}{l}\text { quartzarenites/quartzsiltites } \\
(\mathrm{r})\end{array}$ & $\mathrm{r}$ & + & inactive & $\begin{array}{l}\text { vugs, } \\
\text { cast }\end{array}$ & + \\
\hline M 179/327 (MPP-1) & $\mathrm{MHo} / \mathrm{He}$ & Serial & $\begin{array}{l}\text { coarse silt-fine } \\
\text { sand (rare) }\end{array}$ & 0.4 & $<3 \%$ & $\begin{array}{c}\mathrm{Qtz}(++), \mathrm{Qtz} \mathrm{pol}(++/+), \mathrm{Ms} \\
(++), \mathrm{Kfs}(+/ \mathrm{r}), \mathrm{Pl}(\mathrm{r})\end{array}$ & $\begin{array}{l}\text { quartzarenites/quartzsiltites } \\
(\mathrm{r})\end{array}$ & $\mathrm{r}$ & + & inactive & $\begin{array}{l}\text { vugs, } \\
\text { cast }\end{array}$ & + \\
\hline M 179/377 (MPP-1) & $\mathrm{Ho} / \mathrm{MHo}$ & Serial & $\begin{array}{c}\text { coarse silt-very } \\
\text { fine sand (sporadic) }\end{array}$ & 0.15 & $<3 \%$ & $\begin{array}{c}\mathrm{Qtz}(++), \mathrm{Qtz} \text { pol (+), Ms (+), } \\
\mathrm{Kfs}(\mathrm{r})\end{array}$ & 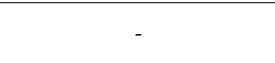 & + & + & inactive & $\begin{array}{l}\text { vugs, } \\
\text { cast }\end{array}$ & + \\
\hline M 179/150 (MPP-2) & MHo & Serial & $\begin{array}{l}\text { coarse silt-fine } \\
\text { sand }\end{array}$ & 0.3 & $10-15 \%$ & $\begin{array}{l}\text { Qtz (+++), } \mathrm{Qtz} \text { pol }(++), \mathrm{Ms} \\
(++/+), \mathrm{Ks}(+), \mathrm{Pl}(+), \mathrm{Gl}(\mathrm{r})\end{array}$ & $\begin{array}{l}\text { quartzarenites/quartzsiltites } \\
(\mathrm{r})\end{array}$ & $++/+$ & + & inactive & $\begin{array}{l}\text { vugs, } \\
\text { cast }\end{array}$ & $++/+++$ \\
\hline M 179/167 (MPP-2) & MHo & Serial & $\begin{array}{l}\text { coarse } \\
\text { silt- }- \text { medium sand }\end{array}$ & 0.8 & $10-15 \%$ & $\begin{array}{c}\mathrm{Qtz}(+++), \mathrm{Qtz} \text { pol }(++), \mathrm{Ms} \\
(++/+), \mathrm{Kfs}(++/+), \mathrm{Pl}(\mathrm{r})\end{array}$ & $\begin{array}{l}\text { acid crystalline rocks (r), } \\
\text { quartzarenites/quartzsiltites } \\
(\mathrm{r})\end{array}$ & + & + & inactive & $\begin{array}{l}\text { vugs, } \\
\text { cast }\end{array}$ & + \\
\hline M 179/171 (MPP-2) & мHo & Serial & $\begin{array}{l}\text { coarse silt-very } \\
\text { fine sand }\end{array}$ & 0.6 & $10-15 \%$ & $\begin{array}{l}\mathrm{Qtz}(+++), \mathrm{Qtz} \operatorname{pol}(++/+), \\
\mathrm{Ms}(++/+), \mathrm{Kfs}(++/+), \mathrm{Pl}(\mathrm{r}),\end{array}$ & $\begin{array}{l}\text { acid crystalline rocks }(\mathrm{r}), \\
\text { quartzarenites/quartzsiltites } \\
(\mathrm{r})\end{array}$ & + & + & inactive & cast & + \\
\hline M 179/158 (MPP-3) & MHo/He & Serial/bimodal & $\begin{array}{l}\text { coarse silt—coarse } \\
\text { sand }\end{array}$ & 0.8 & $15-20 \%$ & $\begin{array}{c}\mathrm{Qtz}(+++/++), \mathrm{Qtz} \text { pol } \\
(++/+), \mathrm{Ms}(+), \mathrm{Kfs}(++/+), \mathrm{Pl} \\
(+/ \mathrm{r})\end{array}$ & $\begin{array}{c}\text { quartzarenites/acid } \\
\text { crystalline rocks }(+)\end{array}$ & + & + & inactive & $\begin{array}{l}\text { vugs, } \\
\text { cast }\end{array}$ & + \\
\hline M 179/160 (MPP-3) & $\mathrm{Ho} / \mathrm{MHo}$ & Bimodal & $\begin{array}{c}\text { coarse } \\
\text { silt-medium sand }\end{array}$ & 0.4 & $15-20 \%$ & $\begin{array}{c}\mathrm{Qtz}(+++), \mathrm{Qtz} \text { pol }(++), \mathrm{Ms} \\
(++), \mathrm{Kfs}_{(++)} \mathrm{Pl}(\mathrm{r})\end{array}$ & $\begin{array}{c}\text { quartzarenites/quartzsiltites } \\
\text { (r) }\end{array}$ & $++/+$ & + & inactive & cast & + \\
\hline M 179/166 (MPP-3) & MH & Serial & $\begin{array}{c}\text { coarse } \\
\text { silt-medium sand }\end{array}$ & 0.5 & $15-20 \%$ & $\begin{array}{l}\text { Qtz (+++), Qtz pol }(++), \text { Ms } \\
(++/+), \text { Kfs }(++/+), \mathrm{Pl}(+/ \mathrm{r})\end{array}$ & $\begin{array}{l}\text { quartzarenite/quartzsiltites } \\
\text { (r), acid crystalline rocks (r) }\end{array}$ & $++/+$ & ${ }^{++}$ & inactive & $\begin{array}{l}\text { vugs, } \\
\text { cast }\end{array}$ & ++ \\
\hline
\end{tabular}

Legend: MHo = Moderately homogeneous; Ho = Homogeneous; He = Heterogeneous $(+++)$ prevalent, $(++)$ common, $(+)$ sporadic, $(\mathrm{r})$ rare; MGS = Maximum Grain Size; Kfs = K-Feldspar; $\mathrm{Pl}=$ Plagioclase; Ms = Muscovite; Qtz = monocrystalline Quartz; Qtz pol = polycrystalline Quartz, $\mathrm{Gl}=$ Glauconite, $\left(^{*}\right)$ only one/few quartz granule/s up to $0.5 \mathrm{~mm}$ size $\left({ }^{* *}\right)$ very thin layer of "burial" calcite only along the external rim of the ceramic sherd (thickness $=0.1-0.3 \mathrm{~mm}$ ) 

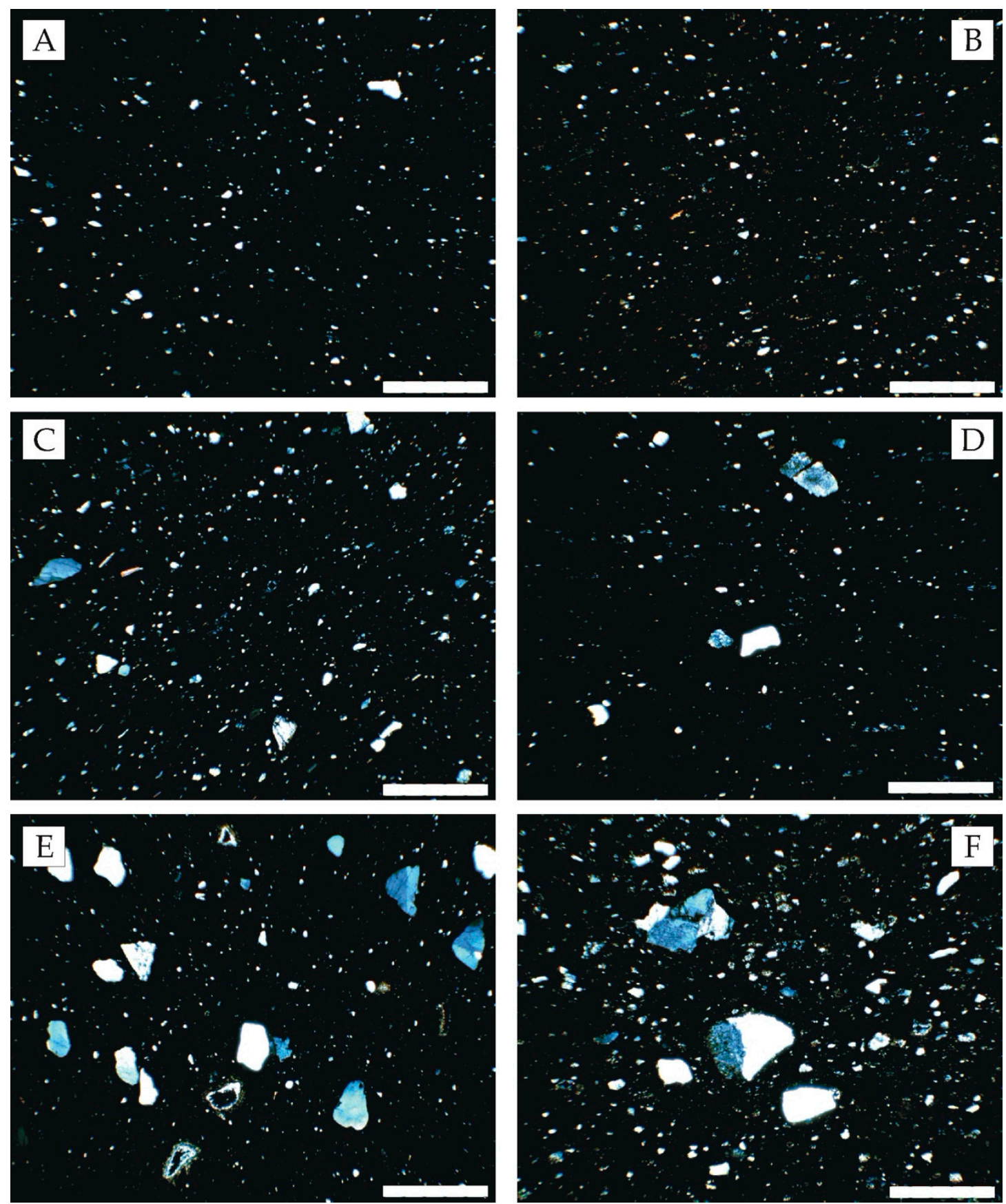

Figure 6. (A) MPP-1: sample M179-157; (B) MPP-1: sample M179-234; (C) MPP-2: sample M179-171; (D) MPP-2: sample M179-161; (E) MPP-3: sample M179-160; (F) MPP-3: sample M179-158 (crossed polar; scale bar $=0.5 \mathrm{~mm}$ ).

The minero-petrographic paste MPP-3 (3 samples out of 16) was easily recognized by a chiefly bimodal (hiatal) distribution of the aplastic inclusions, being the classes of very fine sand $(0.06-0.125 \mathrm{~mm})$ and medium sand $(0.25-0.5 \mathrm{~mm})$, and distinctly more represented than coarse silt $(0.04-0.06 \mathrm{~mm})$ and coarse sand $(0.5-1 \mathrm{~mm})$. Packing was relatively higher, ranging between $15 \%$ and $20 \%$. The smaller aplastic inclusions were generally angular to subangular, while the ones with a diameter greater than $0.3 \mathrm{~mm}$ were subrounded and rarely rounded. Monocrystalline quartz appeared to be by far the most abundant component. Polycrystalline quartz, feldspars (K-feldspar and plagioclase) and white mica (minute crystals $0.04-0.1 \mathrm{~mm}$ homogeneously distributed in the ground-mass) were common to sporadic components. Lithic fragments composed of sandstones, siltstones and acid crystalline 
rocks were subordinate to rare. Calcareous microfossils (or micritic clots and pore casts after the firing process transformation) were basically sporadic rather than common. The ground-mass showed no optical activity, being characterized by some clay lumps and partly impregnated by secondary microcrystalline calcite which developed during the burial phase (Figure 6E,F).

From petrographic observations under a polarizing microscope it appeared that all the samples classified under macroscopic fabric HIM-A-2 (by observation with the naked eye and/or a magnifying glass) fell into the minero-petrographic paste MPP-1 (packing in the region of $<10 \%$ and a predominance of coarse silt), with the exception of a single sample (M 179/167) classifiable as MPP-2 (packing $>10 \%$ and much more fine sand than MPP-1). The minero-petrographic paste MPP-2 comprises two other samples (M 179/150 and M 179/171) which, based on macroscopic observations, fell into the HIM-A-1 fabric (see Table 1). Finally, the MPP-3 microfabric included three samples (M179/166, M179/160 and M179/158), previously classified as HIM-A-1 macrofabric.

\subsection{Chemistry}

Due to the quantity (by weight) of a sample required for the chemical analysis by means of coupled ICP-EOS and ICP-MS (that being at least $5 \mathrm{~g}$ of powdered material), of the selection of 16 samples, only 11 underwent this analytical routine. The results, concerning both major and trace elements and representative of the three minero-petrographic pastes already identified by the thin-section microscopy, are shown in Table 3. For comparison purposes, in the same table, the corresponding concentration values regarding the attested local production of tableware (kylikes Iato K480, data taken from [11]), the clays of the Terravecchia Formation quarried in Contrada Bovitello (at Campofelice di Roccella, a few kilometers from Himera) and the average compositions of the clays of the Terravecchia Formation are also shown [17].

An initial examination of Table 3 shows that the differentiation of the three microfabrics MPP-1, MPP-2 and MPP-3, very evident with microscopic observations, was much more problematic. It seemed to be conditioned by a not-so-negligible contamination of the bulk chemical composition which, most likely, took place during the burial phase. This effect had already been highlighted by the polarizing microscope study, with the recognition of impregnations (in the ground-mass) and incrustations (in the external surface) of secondary calcite. In fact, even a moderate neoformation of calcium carbonate by precipitation from the circulating solutions in the burial soil can affect the $\mathrm{SiO}_{2} / \mathrm{CaO}$ ratio of the considered ceramic pastes, accordingly hiding the increase in $\mathrm{SiO}_{2}$ concentration from MPP-1 to MPP-3, which is in was turn positively correlated to the number and size of silicate aplastic inclusions (being mostly monocrystalline quartz). Consequently, the $\mathrm{SiO}_{2} / \mathrm{CaO}$ ratio seemed to be quite similar for the three identified microscopic pastes, that is: 6.72 for MPP-1, 6.24 for MPP-2 and 6.58 for MPP-3. It should be especially noted that the $\mathrm{SiO}_{2} / \mathrm{CaO}$ ratio itself turned out to be highly variable in the various outcrops of the Terravecchia Formation in western and central Sicily, specifically in relation to the clear difference in the concentration of $\mathrm{CaO}$ and the consequential "dilution effect" [16]. In fact, while the outcrops referable to the basal part of the Tortonian showed average concentrations of $\mathrm{CaO}$ generally lower than $5 \%$ by weight (with a $\mathrm{SiO}_{2} / \mathrm{CaO}$ ratio approximately equal to 14 ), on the contrary, the outcrops referring to the middle-upper part of the Tortonian were between $7 \%$ and $10 \%$ by weight of $\mathrm{CaO}$ (with a $\mathrm{SiO}_{2} / \mathrm{CaO}$ ratio approximately equal to 7 ) and those belonging to the Messinian, due to the presence of detritic gypsum $\left(\mathrm{CaSO}_{4} \cdot 2 \mathrm{H}_{2} \mathrm{O}\right.$ ), reached up to the level of $24 \%$ by weight of $\mathrm{CaO}$ (with a $\mathrm{SiO}_{2} / \mathrm{CaO}$ ratio, approximately equal to 2 ). Overall, considering the average concentrations derived from the analysis of the materials taken only from the Tortonian outcrops (concerning 17 different locations in western Sicily and 121 individual raw clay samples; data taken from [16]), the $\mathrm{SiO}_{2} / \mathrm{CaO}$ ratio of the Terravecchia Formation's clays was equal to 7.95 (average $\mathrm{SiO}_{2}=57.50 \mathrm{wt} \%$, average $\mathrm{CaO}=7.23 \mathrm{wt} \%$ ). The clayey materials of Contrada Bovitello (transition between Tortonian and Messinian, sometimes with small quantities of detritic gypsum) were also slightly richer in $\mathrm{CaO}$ than the regional average of the Terravecchia Formation $\left(\mathrm{SiO}_{2}=54.99 \mathrm{wt} \%, \mathrm{CaO}=9.33 \mathrm{wt} \%, \mathrm{SiO}_{2} / \mathrm{CaO}\right.$ $=5.90$ ). Moreover, an acceptable correspondence of the $\mathrm{SiO}_{2} / \mathrm{CaO}$ ratio was verified between the 
amphoric pastes used in this study and the locally produced tableware $\left(\mathrm{SiO}_{2} / \mathrm{CaO}=7.61\right)$, as shown in Figure 7.

Table 3. LOI normalized chemical composition of the studied western Greek amphorae.

\begin{tabular}{|c|c|c|c|c|c|c|c|c|c|c|c|}
\hline Sample Code & $\begin{array}{l}\text { Micro- } \\
\text { Fabric }\end{array}$ & $\begin{array}{c}\mathrm{SiO}_{2} \\
(\%)\end{array}$ & $\begin{array}{l}\mathrm{Al}_{2} \mathrm{O}_{3} \\
(\%)\end{array}$ & $\begin{array}{c}\mathrm{Fe}_{2} \mathrm{O}_{3} \\
(\%)\end{array}$ & $\begin{array}{c}\mathrm{MnO} \\
(\%)\end{array}$ & $\underset{(\%)}{\mathrm{MgO}}$ & $\begin{array}{l}\mathrm{CaO} \\
(\%)\end{array}$ & $\begin{array}{l}\mathrm{Na}_{2} \mathrm{O} \\
(\%)\end{array}$ & $\begin{array}{c}\mathrm{K}_{2} \mathrm{O} \\
(\%)\end{array}$ & $\begin{array}{l}\mathrm{TiO}_{2} \\
(\%)\end{array}$ & $\begin{array}{c}\mathrm{P}_{2} \mathrm{O}_{5} \\
(\%)\end{array}$ \\
\hline M 179/156 & MMP-1 & 56.63 & 19.31 & 7.61 & 0.06 & 3.24 & 8.69 & 0.97 & 2.29 & 1.01 & 0.18 \\
\hline M 179/159 & MMP-1 & 57.01 & 19.11 & 7.58 & 0.06 & 2.9 & 8.68 & 0.96 & 2.49 & 1.02 & 0.2 \\
\hline M 179/163 & MMP-1 & 56.67 & 19.28 & 7.7 & 0.06 & 2.8 & 8.93 & 1.08 & 2.27 & 1.00 & 0.2 \\
\hline M 179/230 & MMP-1 & 59.12 & 18 & 7.56 & 0.07 & 2.6 & 7.66 & 0.98 & 2.54 & 0.97 & 0.5 \\
\hline M 179/234 & MMP-1 & 58.32 & 19.2 & 7.57 & 0.06 & 2.59 & 7.23 & 1.05 & 2.78 & 1.03 & 0.18 \\
\hline M 179/327 & MMP-1 & 56.34 & 17.5 & 7.19 & 0.1 & 3.55 & 10.04 & 1.32 & 2.93 & 0.85 & 0.19 \\
\hline \multicolumn{2}{|l|}{ MEAN } & 57.35 & 18.73 & 7.54 & 0.07 & 2.95 & 8.54 & 1.06 & 2.55 & 0.98 & 0.24 \\
\hline M 179/150 & MPP-2 & 56.54 & 16.29 & 6.3 & 0.09 & 3.38 & 12.43 & 1.81 & 2.22 & 0.78 & 0.15 \\
\hline M 179/167 & MPP-2 & 61.45 & 16.92 & 7.00 & 0.06 & 2.52 & 7.49 & 1.13 & 2.38 & 0.89 & 0.16 \\
\hline M 179/171 & MPP-2 & 58.08 & 17.31 & 7.21 & 0.09 & 3.52 & 8.29 & 1.6 & 2.9 & 0.83 & 0.15 \\
\hline \multicolumn{2}{|l|}{ MEAN } & 58.69 & 16.84 & 6.84 & 0.08 & 3.14 & 9.40 & 1.51 & 2.50 & 0.83 & 0.15 \\
\hline M 179/160 & MPP-3 & 59.23 & 18.65 & 7.54 & 0.06 & 2.83 & 7.22 & 0.94 & 2.24 & 0.99 & 0.29 \\
\hline M 179/166 & MPP-3 & 57.46 & 16.89 & 6.51 & 0.08 & 3.11 & 10.5 & 1.59 & 2.87 & 0.8 & 0.17 \\
\hline \multicolumn{2}{|l|}{ MEAN } & 58.35 & 17.77 & 7.03 & 0.07 & 2.97 & 8.86 & 1.27 & 2.56 & 0.90 & 0.23 \\
\hline Sample Code & \multicolumn{2}{|c|}{ Micro-Fabric } & $\underset{(\mathrm{ppm})}{\mathrm{V}}$ & $\begin{array}{c}\text { Ba } \\
(\mathrm{ppm})\end{array}$ & $\begin{array}{c}\mathrm{Sr} \\
(\mathrm{ppm})\end{array}$ & $\begin{array}{c}\mathrm{Zr} \\
(\mathrm{ppm})\end{array}$ & $\begin{array}{l}\mathrm{Cu} \\
(\mathrm{ppm})\end{array}$ & $\begin{array}{c}\mathrm{Zn} \\
(\mathrm{ppm})\end{array}$ & $\begin{array}{c}\mathrm{Rb} \\
(\mathrm{ppm})\end{array}$ & $\begin{array}{l}\text { La } \\
(\mathrm{ppm})\end{array}$ & $\begin{array}{c}\mathrm{Ce} \\
(\mathrm{ppm})\end{array}$ \\
\hline M 179/156 & \multicolumn{2}{|c|}{ MMP-1 } & 140 & 978 & 388 & 193 & 40 & 130 & 100 & 49.9 & 100 \\
\hline M 179/159 & \multicolumn{2}{|c|}{ MMP-1 } & 136 & 482 & 360 & 202 & 40 & 120 & 110 & 47.5 & 95.2 \\
\hline M 179/163 & \multicolumn{2}{|c|}{ MMP-1 } & 144 & 347 & 399 & 196 & 30 & 120 & 75 & 45.7 & 90.9 \\
\hline M 179/230 & \multicolumn{2}{|c|}{ MMP-1 } & 136 & 387 & 378 & 204 & 40 & 120 & 117 & 45.8 & 91.1 \\
\hline M 179/234 & \multirow{2}{*}{\multicolumn{2}{|c|}{$\begin{array}{l}\text { MMP-1 } \\
\text { MMP-1 }\end{array}$}} & 138 & 291 & 363 & 200 & 30 & 110 & 115 & 44 & 87.9 \\
\hline M 179/327 & & & 123 & 516 & 467 & 155 & 40 & 110 & 115 & 38.9 & 78.8 \\
\hline \multicolumn{3}{|c|}{ MEAN } & 136 & 500 & 393 & 192 & 37 & 118 & 105 & 45.3 & 90.7 \\
\hline M 179/150 & \multicolumn{2}{|c|}{ MPP-2 } & 116 & 811 & 454 & 161 & 40 & 100 & 72 & 37.2 & 75.7 \\
\hline M 179/167 & \multicolumn{2}{|c|}{ MPP-2 } & 114 & 341 & 342 & 229 & 30 & 100 & 94 & 37.3 & 75.5 \\
\hline M 179/171 & \multicolumn{2}{|c|}{ MPP-2 } & 117 & 446 & 399 & 173 & 40 & 120 & 114 & 40.3 & 81.3 \\
\hline \multicolumn{3}{|c|}{ MEAN } & 116 & 533 & 398 & 188 & 37 & 107 & 93 & 38.3 & 78 \\
\hline M 179/160 & \multicolumn{2}{|l|}{ MPP-3 } & 127 & 523 & 355 & 192 & 30 & 120 & 91 & 43.1 & 88.2 \\
\hline M 179/166 & \multicolumn{2}{|c|}{ MPP-3 } & 113 & 579 & 425 & 159 & 30 & 90 & 109 & 36.8 & 74.2 \\
\hline \multicolumn{3}{|c|}{ MEAN } & 120 & 551 & 390 & 176 & 30 & 105 & 100 & 40.0 & 81.2 \\
\hline Sample Code & $\begin{array}{l}\text { Published } \\
\text { in }\end{array}$ & $\begin{array}{l}\mathrm{SiO}_{2} \\
(\%)\end{array}$ & $\begin{array}{c}\mathrm{Al}_{2} \mathrm{O}_{3} \\
(\%)\end{array}$ & $\begin{array}{c}\mathrm{Fe}_{2} \mathrm{O}_{3} \\
(\%)\end{array}$ & $\underset{(\%)}{\mathrm{MnO}}$ & $\underset{(\%)}{\mathrm{MgO}}$ & $\begin{array}{l}\mathrm{CaO} \\
(\%)\end{array}$ & $\underset{(\%)}{\mathrm{Na}_{2} \mathrm{O}}$ & $\begin{array}{c}\mathrm{K}_{2} \mathrm{O} \\
(\%)\end{array}$ & $\begin{array}{l}\mathrm{TiO}_{2} \\
(\%)\end{array}$ & $\begin{array}{c}\mathrm{P}_{2} \mathrm{O}_{5} \\
(\%)\end{array}$ \\
\hline Iato K480-type & [11] & 56.48 & 19.91 & 8.28 & 0.09 & 3.02 & 7.42 & 0.99 & 2.65 & 1.02 & 0.14 \\
\hline $\begin{array}{c}\text { Terravecchia } \\
\text { Fm-Western Sicily } \\
\text { Terravecchia }\end{array}$ & [17] & 54.91 & 19.68 & 7.48 & 0.09 & 2.53 & 10.91 & 0.79 & 2.67 & 0.98 & 0.14 \\
\hline $\begin{array}{l}\text { Fm-Western Sicily } \\
\text { (Tortonian outcrops) }\end{array}$ & [17] & 57.50 & 20.08 & 8.17 & 0.09 & 2.43 & 7.23 & 0.74 & 2.58 & 1.07 & 0.16 \\
\hline $\begin{array}{c}\text { Terravecchia } \\
\text { Fm-Himera outcrop }\end{array}$ & [17] & 54.89 & 20.1 & 8.04 & 0.07 & 2.52 & 9.3 & 1.04 & 2.69 & 1.01 & 0.12 \\
\hline
\end{tabular}




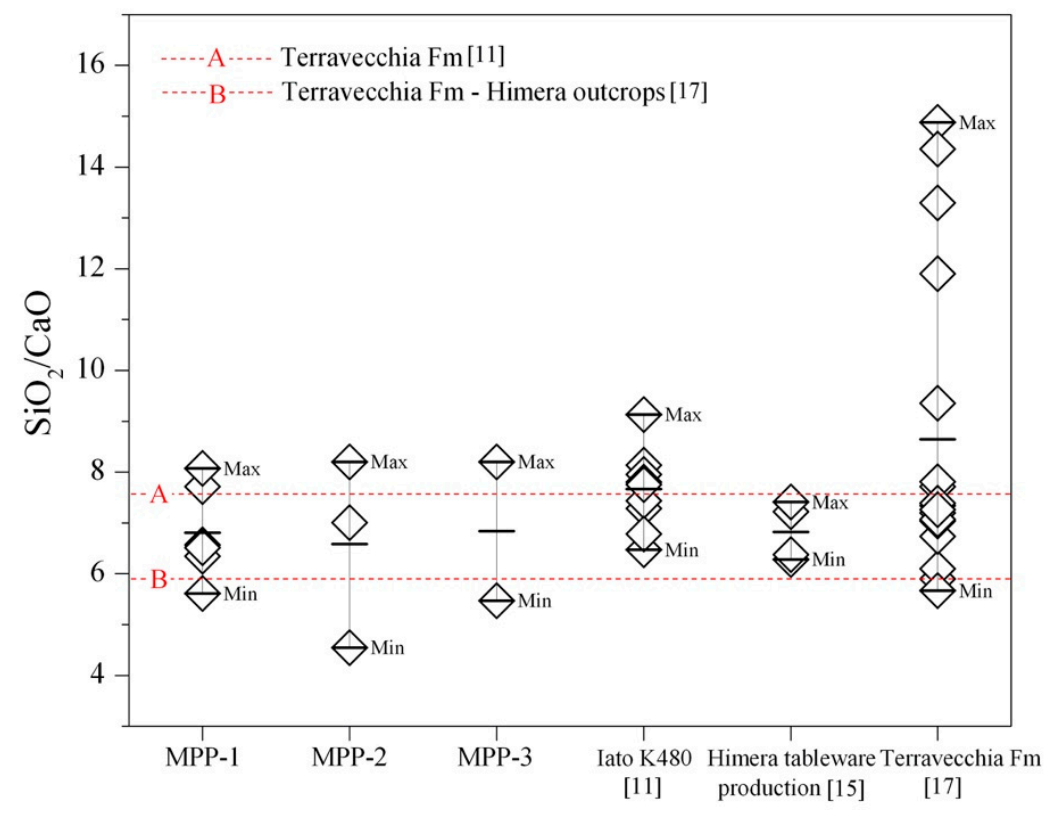

Figure 7. Box plot showing the variation intervals for $\mathrm{SiO}_{2} / \mathrm{CaO}$ ratio compared with those previously established for the productions of Himera.

In addition to $\mathrm{Ca}$, other major elements showed anomalous values in most of the samples examined, proving the hypothesis of a contamination during the burial phase of the ceramic finds. For example, the $\mathrm{Na}_{2} \mathrm{O}$ concentration was abnormally high in several samples $\left(\mathrm{Na}_{2} \mathrm{O}>1.3 \mathrm{wt} \%\right)$ distributed in the three microfabrics identified by optical microscopy. The same can be said for $\mathrm{MgO}$, which was on average close to or greater than $3 \%$ by weight in the representative samples of the three microfabrics. This would lead us to consider the hypothesis of partial contamination by brackish water in the burial environment (necropolis area) as a probable cause. The only chemical markers that would seem to differentiate (for a slightly higher average concentration) the microfabric MPP-1, (characterized by packing $<5 \%$ area and prevailing coarse silt between the aplastic inclusions) from the two microfabrics MPP-2 and MPP-3 (which have relatively higher packing and a greater average size of aplastic inclusions) are $\mathrm{Al}_{2} \mathrm{O}_{3}$, among the major elements, as well as $\mathrm{V}$ and light rare earths (La and Ce) among the trace elements (Figure 8).

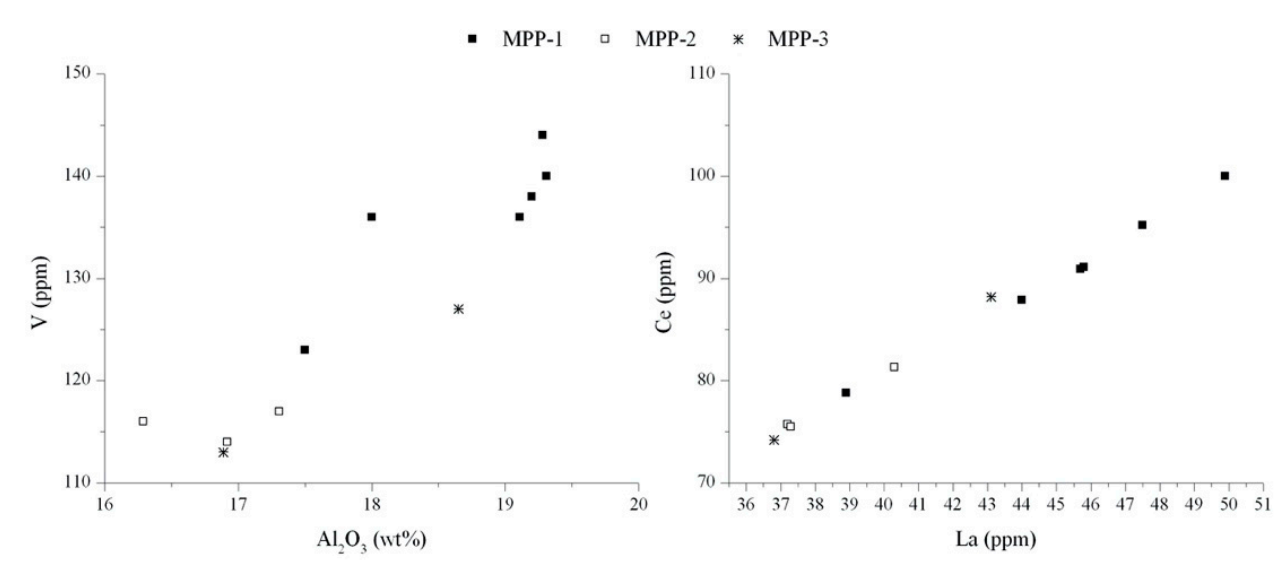

Figure 8. Binary diagrams of $\mathrm{V}-\mathrm{Al}_{2} \mathrm{O}_{3}$ and $\mathrm{La}-\mathrm{Ce}$ for the studied western Greek amphorae.

\section{Discussion}

To date, western Greek form $1 \alpha$ vessels manufactured in Himera over the course of the second half of the 6th century BCE represent the earliest evidence for local amphora production in a Greek-Sicilian colony (for a recent overview on this topic: [21]). In fact, only towards the late-6th century BCE 
did Gela and Agrigento [28], situated along the southern coast, and the Punic emporia of Palermo and/or Solunto [29] close to Himera start fabrication of western Greek form 2 amphorae. However, at present, only Gela's late 6th-5th century BCE series have been satisfactorily characterized from both the archaeometric [30] and archaeological [31] point of view. Hence, the chronological preeminence of Himera's archaic amphorae issue provides essential information about the colony's role and development during the second half of the 6th century BCE within the wider frame of regional and supraregional economic interaction.

In antiquity, the establishment of a transport container manufacturing base implies a supralocal marketing of an agricultural surplus [4]; while the choice of the vessel type is related to the repertoire already in circulation within the regional context [2]. Specifically, shortly after the mid-6th century BCE and contemporaneously to the beginning of local silver coinage, in Himera, the conditions for a profit-oriented exploitation of the resources cultivated in its chora were ripe. From a typological standpoint, local potters imitate South and East Calabrian amphorae, well documented in Himera's second and third-quarter of the 6th century BCE enchytrismoi and presumably regularly distributed in the contemporaneous domestic contexts [21].

The production of western Greek wine amphorae in Himera started at least one generation earlier than in the nearby Punic towns of Palermo and/or Solunto, emphasizing the colony's premature control over its ample hinterland. The probable peak of amphorae fabrication and, by consequence, of trade during the later 6th and early 5th century BCE appears to be perfectly in line with a general trend of widely distributed economic welfare experienced by western Sicily as a whole during the late archaic period. The evident decrease in the local series - or even its possible interruption-in the years after the battle of Himera in 480 BCE and the takeover of control by Agrigento's tyrant Teron during the third decade of the 5th century BCE runs in parallel with an allover reduction or abandonment of the majority of the western Sicilian settlements [32,33]. Finally, the renewal of the production towards the late-5th century BCE also seems to be part of a regional phenomenon of regained economic growth [21].

A last point concerns the distinction, among the analyzed sample group, of two macrofabrics HIM-A-1 and HIM-A-2. HIM-A-1 corresponds almost perfectly to the microfabrics MPP-2 and MPP-3 and includes nearly all of the amphorae dating before ca. $500 \mathrm{BCE}$, together with a selection of vessels attributed to the late Archaic period. By contrast, macrofabric HIM-A-2 matches subfabric MPP-1 and comprises basically late 6th or early 5th-century BCE vessels and the two late 5th-century BCE amphorae. This related, archaeometric and archaeological evidence seems to prove a technological improvement which took place at the beginning of around 500 BCE. Highly interestingly, in the regional context of western Sicily, the transition, during the late 6th and early 5th century BCE, from coarser to finer local fabrics has already been observed for the Punic amphorae productions of Solunto and Mozia [34,35].

\section{Outlook for Further Research}

The present archaeometric case study has contributed substantially to better define one important aspect of Himera's economic development from the second half of the 6th century BCE until its destruction in 409 BCE: a local production of transport amphorae previously unknown and hypothetically linked to the trade of wine. However, who were the principal consumers of these commodities? Himera is not counted among the very few Sicilian Greek colonies, namely Agrigento, Naxos and Syracuse, mentioned by several ancient authors in relation to a systematic exploitation of their notable wine yards [36], and at present, no direct archaeological evidence attests to the cultivation of grapes in its hinterland. What has already been ascertained, however, is the remarkable popularity of the colony's (wine) drinking-vessels of the Iato K480-type, produced during the last third of the 6th and the beginning of the 5th century BCE and widely distributed across native and Punic western Sicily [10,37] especially plate 3, p. 197. The set-up of an amphorae production falls almost exactly within the time-range of these local kylikes mainly destined to non-Greek communities. 
As a working hypothesis, we might interpret namely the local western Greek form 2 amphorae and the cups as being two material expressions of the same phenomenon: trade and exchange of "symbol-objects" and luxurious food and drinking-stuffs with the indigenous élites who aimed to exhibit these prestigious artifacts within the wider frame of ritual ceremonies and banquets [38,39].

Hopefully, the present archaeological and archaeometric characterization of Himera's amphorae series will be helpful in the view of further provenance studies to be conducted on findings from native inland sites of western Sicily. In particular, in order to interpret the chemical variability of the ceramic samples, chemical analyses will be implemented to allow a better correlation with the petrographic data which, in this specific case, were more effective in identifying the minero-petrographic pastes.

Reliable fabric data of such materials are desperately needed in order to make an assessment of the distribution pattern of the colony's amphora production in its chora and beyond.

Author Contributions: Conceptualization, B.B. and G.M.; methodology, B.B and G.M.; formal analysis, B.B., G.M, and L.R.; investigation, B.B., G.M. and L.R.; data curation, B.B., G.M. and L.R.; writing-original draft preparation, B.B., G.M. and L.R.; writing—review and editing, B.B., G.M. and L.R.; supervision, B.B. and G.M.; project administration, B.B.; funding acquisition, B.B. All authors have read and agreed to the published version of the manuscript.

Funding: This research was funded by the Austrian Science Fund (FWF): P 30030-G25, in the frame of the project "Trade of western Greek amphorae from Himera's perspective". Open Access Funding by the Austrian Science Fund (FWF).

Acknowledgments: Special thanks are due to S. Gallagher for his critical input during the correction phase of the English paper. The drawings of Figures 3 and 4 are by G. Guadagnino (Palermo); their composition is due to R. Lampl (University of Vienna). Finally, we thank the authorities of the Soprintendenza BB.CC.AA. di Palermo for the authorization to publish the images and photos of Figures 1, 3 and 4.

Conflicts of Interest: The authors declare no conflict of interest.

\section{References}

1. Vassallo, S. Guida alla storia e ai monumenti, Regione Siciliana, Soprintendenza Beni Culturali ed Ambientali di Palermo-Servizio per i beni archeologici. In Himera. Città Greca; Regione Siciliana: Palermo, Italy, 2005.

2. Gassner, V. Le anfore greco-occidentali: Riconsiderando la loro evoluzione e l'identificazione dei centri di produzioni. In Contacts et acculturations en Méditerranée occidentale. Hommages à Michel Bats (Hyères 2011); Poure, R., Ed.; Maison Méditerranéenne des Sciences de l'Homme: Aix-en-Provence, France, 2015; Études Massaliètes 12; pp. 345-356.

3. Sacchetti, F. Les Amphores Grecques Dans le Nord de l'Italie. Échanges Commerciaux entre les Appennins et les Alpes aux époques Archaïque et Classique; Bibliothèque d'Archéologie Méditerranéenne et Africaine 10: Aix-en Provence, France, 2012.

4. Sourisseau, J.-C.H. La diffusion des vins grecs d'Occident du VIIIe au IVe s. av. J.-C., sources écrites et documents archéologiques, in La vigna di Dioniso: Vite, vino e culti in Magna Grecia. In Proceedings of the Atti del 49 Convegno di Studi sulla Magna Grecia (Taranto 2009), Taranto, Italy, 24-28 September 2009; pp. 145-252.

5. Klug, R.D. Griechische Transportamphoren im regionalen und überregionalen Handel. Untersuchungen in griechischen und nicht-griechischen Kontexten in Unteritalien und Sizilien vom 8. Bis zum 5. Jh. V. Chr; Göttinger Studien zur Mediterranen Archäologie 4: Rahden, Germany, 2013.

6. Vassallo, S. Bibliografia ragionata sulle necropoli di Himera. In Notiziario Archeologico della Soprintendenza di Palermo n. 30; Regione Siciliana: Palermo, Italy, 2018; pp. 1-15.

7. De Bonis, A.; Gassner, V.; Ntaflos, T.; Rizzo, M.L.; Sauer, R.; Serritella, A.; Vassallo, S.; Bechtold, B. 5th-Century BC HIMERA and the campanian connection: Petrographic and archaeological studies on western greek amphorae from poseidonia and elea unearthed in the Necropolis of Himera. Minerals 2020, 10, 227. [CrossRef]

8. Vassallo, S. Gli spazi del sito e dell'abitato di Himera. In L'espai a Grècia III: Anomenar l'espai; Jufresca, M., Gaia, O., Eds.; INST. Catala D’arqueologia Classica: Tarragona, Spain, 2013; pp. 75-91.

9. Olcese, G. Atlante dei siti di produzione ceramica (Toscana, Lazio, Campania e Sicilia) con le tabelle dei principali relitti del Mediterraneo occidentale con carichi dall'Italia meridionale IV secolo a.C.-I secolo d.C. In Collana Immensa Aequora 2; Quasar Edizioni: Roma, Italy, 2012; p. 704. ISBN 97888-7140-451-6. 
10. Vassallo, S. Coppe tipo “Iato K480". In Colle Madore. Un caso di Ellenizzazione in Terra Sicana; Nuova Graficadue: Palermo, Italy, 1999; pp. 199-211.

11. Alaimo, R.; Giarrusso, R.; Montana, G. Primi dati archeometrici sulle coppe tipo “Iato K480". In Colle Madore. Un caso di Ellenizzazione in Terra Sicana; Vassallo, S., Ed.; Nuova Graficadue: Palermo, Italy, 1999; pp. 273-282.

12. Alaimo, R.; Giarrusso, R.; Iliopoulos, I.; Montana, G. Coppe Iato K480: Analisi archeometriche finalizzate alla determinazione del centro di produzione. In Atti del I Congresso Nazionale della Società Italiana di Archeometria, (Verona 23-Dicembre 1999); Patron Editore: Bologna, Italy, 2000; pp. 405-417.

13. Montana, G.; Caruso, A.; Lavore, A.T.; Polito, A.M.; Sulli, A. Inquadramento geologico e definizione composizionale delle "argille ceramiche" presenti nella Sicilia nord-occidentale: Ricadute di carattere archeometrico. II Quat. 2006, 19, 277-296.

14. Montana, G.; Bonsignore, C.; Belvedere, O.; Burgio, A.; Greco, C.; Tardo, V.; Spatafora, F. La produzione di ceramica da mensa a Solunto: Un esempio di continuità tecnologica dall'età Arcaica a quella Ellenistico-Romana. In Le Classi Ceramiche. Situazione Degli Studi-Atti della 10a Giornata di Archeometria della Ceramica (Roma, 57-aprile 2006); Gualtieri, S., Fabbri, B., Bandini, G., Eds.; Edipuglia: Bari, Italy, 2009; p. 272. ISBN 8872285674.

15. Montana, G.; Iliopoulos, I.; Tardo, V.; Greco, C. Petrographic and geochemical characterization of archaic-hellenistic tableware production at solunto, Sicily. Geoarchaeology 2009, 24, 86-110. [CrossRef]

16. Montana, G.; Polito, A.M.; Caruso, A.; Sulli, A. Le «Argille Ceramiche» Della Sicilia Occidentale e Centrale; IlionBooks: Enna, Italy, 2011; p. 204.

17. Montana, G.; Cau Ontiveros, M.A.; Polito, A.M.; Azzaro, E. Characterisation of clayey raw materials for ceramic manufacture in ancient Sicily. Appl. Clay Sci. 2011, 53, 476-488. [CrossRef]

18. Hunt, A.M.W. The Oxford Handbook of Archaeological Ceramic Analysis; Oxford University Press: Oxford, UK, 2016; p. 724.

19. Trapichler, M. Fabrics of Himera, in FACEM (Version 06/06/2011). Available online: http://www.facem.at/ project-papers.php (accessed on 21 July 2020).

20. FACEM; Gassner, V.; Trapichler, M.; Bechtold, B. (Eds.) Provenance Studies on Pottery in the Southern Central Mediterranean from the 6th to the 2nd c. B.C. Available online: http://www.facem.at/project-papers.php (accessed on 21 July 2020).

21. Bechtold, B.; Vassallo, S.; Ferlito, F. La produzione delle anfore greco-occidentali di Himera: Uno studio sulla loro identificazione. In Notiziario Archeologico della Soprintendenza di Palermo n. 51; Regione Siciliana: Palermo, Italy, 2019; pp. 1-21.

22. Gassner, V. Materielle Kultur und kulturelle Identität in Elea in spätarchaisch-frühklassischer Zeit. In Untersuchungen zur Gefäß-und Baukeramik aus der Unterstadt (Grabungen 19871994-) (Archäologische Forschungen 8. Velia-Studien 2); Verlag der Österreichischen Akademie der Wissenschaften: Wien, Austria, 2003.

23. Abate, B.; Renda, P.; Tramutoli, M. Note illustrative della carta geologica dei monti di Termini Imerese e delle Madonie Occidentali. Sicilia Centro Settentrionale. Mem. Soc. Geolologica Ital. 1988, 41, 475-505.

24. Catalano, R.; Avellone, G.; Basilone, L.; Contino, A.; Agate, M. Note Illustrative della Carta Geologica d'Italia alla scala 1:50,000 Foglio 609596-Termini Imerese-Capo Plaia, Istituto Superiore per la Protezione e la Ricerca Ambientale; Servizio Geologico d' Italia, Regione Siciliana-Assessorato Territorio ed Ambiente: Palermo, Italy, 2010; p. 211.

25. Catalano, R.; Avellone, G.; Barchi, M.; Di Maggio, C.; Contino, A.; Gennaro, C.; Bonomo, S.; Gasparo Morticelli, M. Carta Geologica d'Italia alla scala 1:50,000 del Foglio 609596- "Capo Plaia-Termini Imerese"; Progetto CARG_ISPRA (Istituto Superiore per la Protezione e la Ricerca Ambientale): Rome, Italy, 2007.

26. Matthew, A.J. Spots before the eyes: New comparison charts for visual percentage estimation in archaeological material. In Recent Developments in Ceramic Petrology; Middleton, A., Freestone, I., Eds.; British Museum: London, UK, 1991; pp. 211-263.

27. Cau Ontiveros, M.A.; Day, P.M.; Montana, G. Secondary calcite in archaeological ceramics: Evaluation of alteration and contamination processes by thin section study. In Modern Trends in Scientific Studies on Ancient Ceramics. British Archaeological Reports (BAR), Proceedings of the 5th European Meeting on Ancient Ceramics, Athens, Greece, 1820-October 1999; Kilikoglou, V., Hein, A., Maniatis, Y., Eds.; International Series 1011 Archaeopress: Oxford, UK, 2002; pp. 9-18. 
28. Baldoni, V.; Parello, M.C.; Scalici, M. New researches on Pottery workshops in Akragas. Excavations in the artisanal area outside Gate 5 (excavation 2019). Ocnus 2019, 27, 107-116.

29. Bechtold, B.; Vassallo, S. Le anfore puniche dalle necropoli di Himera (seconda meta del VII-Fine del V sec. A.C.) (Babesch Supplements); Peeters: Leuven, Belgium, 2018; Volume 34, p. 188. ISSN 978-90-429-3604-1.

30. Barone, G.; Paolo, M.; Spagnolo, G.; Aquilia, E. The transport amphorae of Gela: A multidisciplinary study on provenance and technological aspects. J. Archaeol. Sci. 2012, 39, 11-22. [CrossRef]

31. Spagnolo, G. La produzione di anfore da trasporto a Gela. In A Madeleine Cavalier; Bernabò Brea, M., Cultraro, M., Gras, M., Martinelli, M.C., Pouzadoux, C., Spigo, U., Eds.; Centre Jean Bérard: Naples, Italy, 2018; pp. 281-294.

32. Vassallo, S. Guerre e conflitti nella Sicilia centro-occidentale tra la metà del VI e la fine del V sec a.C.: Una prospettiva archeologica. In The fight for Greek Sicily. Society, Politics, and Landscapes; Jonasch, M., Ed.; Oxbow Books: Oxford, UK, 2020; pp. 1-17.

33. Vassallo, S. Abitati indigeni ellenizzati della Sicilia centro-occidentale dalla vitalità tardo-arcaica alla crisi del V sec. a.C. In Terze Giornate Internazionali di Studi sull'area elima (Gibellina 1997); Scuola Normale Superiore di Pisa: Pisa-Gibellina, Italy, 2000; pp. 983-1008.

34. Bechtold, B. (a cura di) Le produzioni di anfore puniche della Sicilia occidentale (VII-III/II sec. a.C.) (con i contributi di G. Montana, L. Randazzo e K. Schmidt). Carthage Stud. 2015, 9, 203.

35. Montana, G.; Randazzo, L. Le ricerche archeometriche: La caratterizzazione delle produzioni di anfore punico-siciliane, in Le produzioni di anfore puniche della Sicilia occidentale (VII-III/II sec. a.C.). Carthage Stud. 2015, 9, 118-146.

36. Van Der Mersch, C. Vigne, vin et économie dans l'Italie du Sud grecque à l'époque archaïque. Ostraka 1996, 1, 155-187.

37. Caflisch, R.B. Studia Ietina IV. In Die Firniskeramik vom Monte Iato. Funde 1971-1982; Isler, H.P., Ed.; Rentsch Verlag: Zürich, Switzerland, 1992.

38. Kistler, E. Connected: Cultura simposiale intermediterranea e i gruppi elitari nella Sicilia arcaica, in Atti delle Seste Giornate Internazionali di Studi sull'Area Elima e la Sicilia occidentale nel contesto Mediterraneo (Erice 2006); Scuola Normale Superiore di Pisa: Pisa, Italy, 2009; pp. 743-761.

39. de Cesare, M. Aspetti del sacro a Segesta tra l'età arcaica e la prima età classica. In Sanctuaries and the Power of Consumption Networking and the Formation of Elites in the Archaic Western Mediterranean World. Proceedings of the International Conference in Innsbruck 2012, Philippika. Altertumswissenschaftliche Abhandlungen, 82, Innsbruck, Austria, 30 September-5 October 2012; Kistler, E., Öhlinger, B., Mohr, M., Hoernes, M., Eds.; Harrassowitz Verlag: Wiesbaden, Germany, 2015. 